\title{
Corrosion Inhibitory Effects of Mullite in Concrete Exposed to Sulfuric Acid Attack
}

\author{
Shima Taheri ${ }^{1, * \mathbb{C}}$, Gerardo Pareja Delgado ${ }^{1,2}$, Oluwatoosin B. A. Agbaje ${ }^{1,3} \mathbb{B}$, Paritosh Giri ${ }^{1} \mathbb{C}$ \\ and Simon Martin Clark ${ }^{1}$ \\ 1 Faculty of Science and Engineering, Macquarie University North Ryde, Macquarie Park, \\ NSW 2109, Australia; g.pareja.d@outlook.com.au (G.P.D.); toosin.agbaje@mq.edu.au (O.B.A.A.); \\ paritosh.giri@mq.edu.au (P.G.); simon.clark@mq.edu.au (S.M.C.) \\ 2 Faculty of Science, University of New South Wales, Kensington, NSW 2052, Australia \\ 3 Department of Earth Sciences, Palaeobiology, Uppsala University, 75236 Uppsala, Sweden \\ * Correspondence: shima.taheri@mq.edu.au; Tel.: +61-298-504-725
}

Received: 30 July 2020; Accepted: 25 August 2020; Published: 1 September 2020

\begin{abstract}
Prolonged exposure to low $\mathrm{pH}$ conditions affects the durability of concrete. In this work, the effect of mullite, aluminum silicate, on the strength and the acid corrosion of mortar and concrete under induced accelerated conditions in sulfuric acid solutions at $\mathrm{pH}$ of 0.25 and 1 was studied. The characterization of physicochemical changes was performed using techniques including compressive strength, scanning electron microscopy, micro-X-ray fluorescence spectrometry, and the Vickers hardness test. The results indicate that the addition of mullite does not have any significant effect on the overall strength of mortar and concrete samples, while it significantly increases their resistance to corrosion caused by sulfate attack by $90 \%$, therefore, it is expected to increase the life span and decrease the maintenance costs of concrete pipes subjected to acid corrosion in sewer environments. The inhibition efficiency is observed to be sensitive to acid concentration and was improved with increase in the amount of mullite in samples.
\end{abstract}

Keywords: corrosion inhibition; mullite; concrete corrosion; durability; acid corrosion

\section{Introduction}

Concrete durability depends on the environment that it is exposed. Concrete corrosion has been identified as one of the significant factors that affects the durability and integrity of a concrete structure. Sewer systems, underground structures, roads, culverts, marine and hydraulic structures are among the most critical infrastructure assets for modern urban societies and are highly affected by concrete corrosion [1-4]. Acid attack, a form of the chemical attack on concrete subjected to low $\mathrm{pH}$ environments, causes microstructural changes in concrete due to the dissolution and leaching of acid-susceptible elements from the cement paste [4,5]. Acid attack on concrete structures might occur either in the form of chemical attack or microbiological activity. Chemical attack on concrete, such as slabs, floors and concrete overlays, can be due to the exposure to acidic rainwater in that the dissolution of $\mathrm{CO}_{2}, \mathrm{SO}_{2}$ and $\mathrm{NO}_{x}$ in rainwater reduces the $\mathrm{pH}$ to $4-5$ [1,6]. In sewer pipes, the chemical attack happens mainly below the water lines and is due to the presence of acids and other chemicals in the waste stream, in addition to the acidic rainwater [2,6]. The biogenic acid attack causes failure of the concrete and is the main complex attack in the sewage systems, industrial wastewater tunnels (above the water lines and the crown areas) and treatment plants, agricultural silos and fermenters, and cooling towers at power plants $[1,7,8]$. The reaction between the calcium hydroxide and other products of hydration with acid produces soluble salts [5,9-12], which are easily removable from the cement paste [13-15]. This can lead to a loss of bonds between the coarse aggregate particles 
and the cement paste most analogous to the osteoporosis [16], which can eventually increase the risk of structural failure. The maintenance and retrofitting of degraded concrete structures cost a huge amount of money yearly, due to, for instance, sulfuric acid $\left(\mathrm{H}_{2} \mathrm{SO}_{4}\right)$ attack on concrete [17]. In particular, $\mathrm{H}_{2} \mathrm{SO}_{4}$ is the most aggressive mineral acid found in the natural environment, that not only produces highly soluble calcium salts but also initiates the sulfate attack, another form of chemical attack. The expansive reactions of the sulfate salt materials in the concrete lead to the deterioration trend of concrete strength and finally to structural failure [18].

Microbiologically generated sulfuric acid can attack concrete in a multi-stage biodegradation process and consists of the involvement of various microorganisms which results in the corrosion of concrete and reinforcement $[4,7,8,19-22]$. Sulfate-reducing bacteria, which are heterotrophic bacteria found in almost any environmental sample, have the capability to convert sulfate into hydrogen sulfide $\left(\mathrm{H}_{2} \mathrm{~S}\right)$ [20]. The $\mathrm{H}_{2} \mathrm{~S}$ and carbon dioxide as well as other substances with acidic properties interact at the concrete surface to lower the $\mathrm{pH}$ of concrete at about 12.5 to $\sim 9$. Previous findings suggested that neutrophilic sulfur oxidizing bacteria (SOB) can oxidize $\mathrm{H}_{2} \mathrm{~S}$ and other reduced sulfur compounds to sulfuric acid $\left(\mathrm{H}_{2} \mathrm{SO}_{4}\right)$ and polythionic acids $\left[\mathrm{Sn}\left(\mathrm{SO}_{3} \mathrm{H}\right)_{2}\right.$, where $\left.n>2\right]$ which, in turn, decrease the $\mathrm{pH}$ to $\leq 5.0$ [21]. Different types of $\mathrm{SOB}$ are involved in sulfur oxidation process that influenced the production of $\mathrm{H}_{2} \mathrm{SO}_{4}$ and eventually result in a decrease of $\mathrm{pH}$ to about 1.0 [21,22]. This type of attack is the leading source of structural failure in gravity sewer pipes. If not controlled, the corrosion rate can be several millimeters per year $[6,23,24]$. On average a sewer pipe corrodes at a rate of $1-3 \mathrm{~mm}$ per year. The concrete corrosion can cost hundred million dollars in Australia alone. Management of long-term concrete corrosion is a major challenge to water utilities and they are continuously attempting to extend wastewater assets' service life and to lower the rate of corrosion through reduction of the humidity and $\mathrm{H}_{2} \mathrm{~S}$ gas levels, treatment of the wastewater or surface treatment of the concrete pipe, and the installation of more durable pipes $[25,26]$. A low water to cement $(w / c)$ ratio and lower permeability can make concrete more durable. The optimization of the concrete mix design and reducing the availability of $\mathrm{Ca}(\mathrm{OH})_{2}$ and tricalcium aluminate $(\mathrm{C} 3 \mathrm{~A})$ in hydrated concrete, when used in locations routinely exposed to low $\mathrm{pH}$ conditions and sulfate ions, can also help make concrete more robust $[27,28]$. This optimization can be through using cement with suitable chemical compositions (such as sulfate resisting cement), using aggregates with minimal risk of alkali-silica reaction, using admixtures (such as water-repellent additives, air-entraining additives), using supplementary cementitious materials (such as fly ash and silica fume), and using polymer modified binders [1,12,14,17].

Changing the chemistry of the clinker (e.g., addition of the limestone to reduce the $\mathrm{C} 3 \mathrm{~A}$ ) and the use of alternative cements, i.e., sulfate resistance cement, calcium sulfoaluminate cement, are effective approaches in improving the resistance of concrete to lower $\mathrm{pH}$ [29-33]. The addition of supplementary cementitious materials (SCMs) to concrete mix, however, have been highlighted as the most promising approach in enhancing concrete durability when exposed to low $\mathrm{pH}$ environments. Materials such as fly ash, slag, silica fume and high alumina cement can improve concrete properties such as compressive strength, abrasion resistance and resistance to sulfate and acid attack [34-40]. Mineral admixtures can fill in the matrix voids due to their smaller size and have the pozzolanic activity with the ability to produce the additional calcium silicate hydrate (C-S-H) gel in later stages. Therefore, the use of mineral admixtures in concrete results in a denser structure and a slower rate of external invasive ions ingress [37]. The partial replacement of cement with mineral admixtures also reduces the hydration products susceptible to corrosion. Fly ash which is mainly made of oxides of silicon, aluminum, iron and calcium, is a popular SCM for durability improvement in concrete and comes in two forms: Class $\mathrm{C}$ and Class $\mathrm{F}[34,40]$. The main difference between Class $\mathrm{C}$ and $\mathrm{F}$ is the quantity of calcium, silica, alumina, and iron content in the ash. The Class $\mathrm{F}$ fly ash provides good sulfide and sulfate resistance to concrete due to low calcium ash, while Class $\mathrm{C}$ has higher calcium contents and good pozzolanic properties which can improve the early strength properties of the concrete $[34,40]$. A ground granulated blast-furnace slag (GGBS) contains a large number of alumina and can minimize the adverse impact of free chlorine ions on the corrosion reinforcement thus improving the resistance to seawater corrosion 
of the marine structures [41]. Using silica fume (SF), submicron particles of silicon dioxide, in concrete have multiple benefits from improving early compressive strength to resistance of chemical attack of, instance, chlorides and acids. The silica fume influences the thickness of the transition phase between the aggregate particles and cement paste thus strengthening the cement-aggregate bond. It can also influence the orientation of the $\mathrm{CH}$ crystals resulting in a less porous and more homogenous microstructure in the interfacial region $[33,41,42]$. Calcium aluminate cement (CAC) consists mainly of calcium aluminate (CA) and calcium dialuminate (CA2) phases and have proven resistance to sulfate attack due to the presence of a protective coating of alumina gel. In addition, the reaction products of CAC with sulfate have low reactivity and do not contain $\mathrm{Ca}(\mathrm{OH})_{2}$. The reaction between the available $\mathrm{Ca}(\mathrm{OH})_{2}$ in hydrated cement matrix with sulfate produces gypsum (calcium sulfate dihydrate), and leads to softening and loss of concrete strength [36,37].

The longevity of Roman structures is due to its concrete mixture and it's high durability is due to the presence of phillipsite and aluminous tobermorite crystals $[43,44]$. These crystals are formed due to the chemical reaction between cement and aluminium silicates, and the only component of Roman concrete composing aluminium silicates is the volcanic ash which significantly consists of aluminous tobermorite. The presence of these crystals account for the high durability and possible compressive strength $[43,44]$. Previous study showed that the addition of amorphous alumina silicate to concrete has multiple benefits [45], from increasing concrete's compressive strength, freeze-thaw resistance, density, and the reduction of water absorption. The use of zeolites, hydrated crystalline aluminosilicates with three-dimensional framework, in concrete have recently gained attention in increasing concrete resistance to sulfate attack and freeze/thaw [46,47]. This technique has been shown to reduce the porosity in concrete and hence produced a denser matrix. Cenospheres [48] and mullites [49] are also two materials made largely of silica and alumina. We chose mullite $\left(3 \mathrm{Al}_{2} \mathrm{O}_{3} \cdot 2 \mathrm{SiO}_{2}\right.$ or $\left.\mathrm{Al}_{6} \mathrm{Si}_{2} \mathrm{O}_{13}\right)$ as it can be found both in natural as well as in synthetic forms and has high temperature and corrosion stability, and high electrical resistivity. Unlike other minerals, Natural mullite is an uncommon material which was discovered on the Island of Mull (Inner Hebrides, Scotland) and can be found in other parts of Europe (Ireland, Italy, Germany, Russia), and South Africa. Synthetic mullite, however, is a popular material in refractories and the steel industries are largest consumers, followed by glass and the ceramic industries.

The aim of this study was to reduce or ideally inhibit the corrosion of concrete caused by sulfuric acid attack by repurposing mullite as a prospective corrosion inhibitor. We investigated the addition of $5 \%$ and $10 \%$ (parts by weight) of synthetic mullite to mortar and concrete formulations. Within the scope of this study, changes in water absorption, compressive strength, elemental composition, rate of corrosion, microstructural and hardness of the cement-paste of mortar and concrete specimens exposed to sulfuric acid at $\mathrm{pH}$ of 0.25 and 1 are measured at different time intervals.

\section{Materials and Methods}

Cement type General Purpose (GP) from Bastion (Independent Cement \& Lime, Australia, properties are described in Table 1), white washed sand and coarse aggregate $\left(\sim 7 \mathrm{~mm}^{3}\right.$ dimension) from Building Materials, were all obtained from Bunnings Warehouse Australia (Australia). Sulfuric acid of purity 95-97\% and aluminum silicate/Mullite $\left(3 \mathrm{Al}_{2} \mathrm{O}_{3} 2 \mathrm{SiO}_{2}, \mathrm{CAS} 37287-16-4\right)$ were supplied by Sigma-Aldrich (USA). Epofix Resin and Hardener were obtained from Struers ApS (Ballerup, Denmark). Tap water of $\mathrm{pH} \approx 7.8$ (properties are described in Table 2) was used for the duration of the study.

Mix proportions: Three mortars and three concrete mixtures have been used in this study, as presented in Table 3. A laboratory designed mortar and concrete formulation was used as a guideline for preparation of control (ctrl) samples (F1 and F4):

- Control concrete: cement, sand, and aggregate (ratio 3:2:5) and water.

- Control mortar: cement, sand (ratio 3:7), and water. 
Mullite (aluminum silicate) was added at the ratio of $5 \%$ and $10 \%$ of the proportion of the masses of cement to these formulations, as shown in Table 3. None of these two formulations contained special-purpose admixtures for improving the resistance of the concrete to sulfuric acid attack. The casting of specimens into cubic molds $\left(50 \times 50 \times 50 \mathrm{~mm}^{3}\right)$ and cylindrical molds $(75 \mathrm{~mm} \times 150 \mathrm{~mm})$ was started immediately upon completion of mixing. A shaker was used to reduce air bubble content trapped within the cement mixture. Specimens were demolded $24 \mathrm{~h}$ after casting and then immersed in a water bath for the duration of 28 days. Cubic samples were used for SEM, $\mu-X R F$, and hardness tests while cylindrical specimens were used for the compressive strength tests.

Table 1. Chemical and physical properties of the cement binder provided by the manufacturer.

\begin{tabular}{ccc}
\hline Properties & Test Method & Results \\
\hline $\mathrm{SiO}_{2}$ & AS2350.2 & $19.10 \%$ \\
$\mathrm{Al}_{2} \mathrm{O}_{3}$ & AS2350.2 & $5.10 \%$ \\
$\mathrm{Fe}_{2} \mathrm{O}_{3}$ & $\mathrm{AS} 2350.2$ & $3.00 \%$ \\
$\mathrm{CaO}$ & $\mathrm{AS} 2350.2$ & $63.60 \%$ \\
$\mathrm{MgO}$ & $\mathrm{AS} 2350.2$ & $1.40 \%$ \\
$\mathrm{Na}{ }_{2} \mathrm{O}$ & $\mathrm{AS} 2350.2$ & $0.50 \%$ \\
Equivalent Loss on Ignition & AS2350.2 & $4.20 \%$ \\
Fineness Index Normal & AS2350.8 & $375 \mathrm{~m} / \mathrm{kg}$ \\
Chloride Ion & BH-TM-0507 & $0.01 \%$ \\
\hline
\end{tabular}

Table 2. Chemical and physical properties of the tap water.

\begin{tabular}{cccccccc}
\hline Parameter Unit & $\mathrm{Al}^{3+} \mathbf{~ m g} / \mathrm{L}$ & $\mathrm{Ca}^{2+} \mathbf{~ m g} / \mathrm{L}$ & $\mathrm{Fe}^{2+} \mathbf{~ m g} / \mathrm{L}$ & $\mathrm{Mg}^{2+} \mathbf{~ m g} / \mathrm{L}$ & $\mathrm{Si}^{2+} \mathbf{~ m g} / \mathrm{L}$ & $\mathrm{pH}$ & Temperature ${ }^{\circ} \mathrm{C}$ \\
\hline Results & 0.257 & 265.624 & 0.0282 & 14.730 & 3.535 & 7.8 & 23 \\
\hline
\end{tabular}

Table 3. Mortar and concrete formulations (in percentage by weight) for the preparation of mortar and concrete samples.

\begin{tabular}{ccccccc}
\hline \multirow{2}{*}{ Material/ID } & \multicolumn{3}{c}{ Mortar } & \multicolumn{3}{c}{ Concrete } \\
\cline { 2 - 7 } & F1 & F2 & F3 & F4 & F5 & F6 \\
\hline Cement & 30 & 25 & 20 & 30 & 25 & 20 \\
Sand & 70 & 70 & 70 & 20 & 20 & 20 \\
Aggregate & - & - & - & 50 & 50 & 50 \\
Mullite & - & 5 & 10 & - & 5 & 10 \\
\hline Total & 100 & 100 & 100 & 100 & 100 & 100 \\
\hline Water & 13 & 18.7 & 19.7 & 12.5 & 16 & 16.6 \\
\hline
\end{tabular}

The concentrated sulfuric acid was diluted with water to the desired $\mathrm{pH}$ and cubic samples were tested under static accelerated acid corrosion in the sulfuric acid solution of $\mathrm{pH} 0.25$ for 2 weeks, and another set of samples in $\mathrm{pH} 1$ for varying durations of 1 month and 3 months. After each test cycle, each sample was washed thoroughly with water and dried at room temperature. A visual inspection was performed to assess any physical change in the sample and the depth of corrosion was measured before mechanical and microanalysis assessment.

Equipment: The compression test of cylindrical specimens was conducted following ASTM C39/C39M-18 Standard [50] using an Instron 8036 Testing Machine (Instron, USA) with a 10,000 kN static compressive load. The loading rate was $0.25 \pm 0.05 \mathrm{MPa} / \mathrm{s}$. The tests were conducted at ambient temperature, and the averaged results of three samples were recorded. The sectioned cores were imaged, and elemental distribution maps were collected using a scanning electron microscope (SEM) and X-ray fluorescence (XRF) techniques. A Phenom XL Benchtop scanning electron microscope (Thermo Scientific, Waltham, MA, USA) with a Cerium Hexaboride (CeB6) electron source was used for microstructural analysis (resolution $\leq 20 \mathrm{~nm}$, electron magnification range: 80-100,000 $\times$, detectors: 
BSD (backscattered), SED (secondary) and EDS). Micro-XRF ( $\mu$-XRF) mapping was performed using an M4 Tornado Brucker (Bruker, Billerica, MA, USA). The M4 Tornado was equipped with a Rh anode tube and measurements were conducted at $50 \mathrm{kV}$ and $199 \mu \mathrm{A}$, with $35 \mu \mathrm{m}$ pixel size, and with the samples under 4.9 mbar vacuum. The Advanced Mineral Identification and Characterization System (AMICS) software (Bruker Corp., Billerica, MA, USA) compared the X-ray spectra from each pixel with spectra from pure mineral standards and assigned a mineralogical identity to each pixel. The hardness of specimens (set in EPOFIX epoxy resin) was measured using micro/macro hardness tester "DuraScan 20" (Struers A/S, Copenhagen, Denmark) with objective lens 20× (HV2-HV3) and 40× (HV0.3-HV1) and a test load range $0.098 \mathrm{~N}-98.1 \mathrm{~N}$ method. Dissolved mineral levels in the tap water were measured using a Varian Vista AX CCD inductively coupled plasma atomic emission spectrometry (ICP-AES, Varian, Mulgrave, Australia) and standard procedures. Corroded byproducts obtained from the bottom of the acid bath were analyzed using a Nicolet iD5 ATR Fourier transform infrared (FTIR) Spectrophotometer (Thermo Scientific, Waltham, MA, USA) over wavenumber range of 500 to $4000 \mathrm{~cm}^{-1}$.

\section{Results and Discussion}

Samples containing $5 \%$ and $10 \%$ of mullite, see Table 3 formulation guideline, needed more water to meet the same consistency of F1 and F4 samples (based on ASTM C187-16 [51] method, data not reported). This is in contrast to the previous study [45] that demonstrated the use of amorphous Al-Si resulted in low water absorption. Unlike the Nagrockiene et al. study, the present study did not use any superplasticizer. There is a significant difference between the water absorption of the control $(0 \%)$ and the $5 \%$ mullite samples of both mortar and concrete formulations, but there was less than 5\% difference between the water absorption of F2 and F3 and also between F5 and F6 samples. Mortar samples, in general, required more water compared to concrete samples since as the sand particles have more surface area compared to coarse aggregates.

According to the previous studies, higher aluminum and silica content corresponds to higher strength in concrete $[45,52,53]$. However, the compression test on cylindrical samples containing 0,5 , and 10 weight percent mullite (Figure 1) showed no significant strength improvement by using mullite. The use of excess water in preparing samples and the absence of superplasticizer are two contributing factors to this finding. These test results can be further explained with the expectation of that by Abram's Law [54], the increase in w/c ratio is inversely proportional to the strength. While concluding that there is no significant strength improvement with the addition of mullite, the test results remained relatively consistent, regardless of the increased $\mathrm{w} / \mathrm{c}$ ratio (Figure 1). Thus, indicating mullite has some strengthening effect towards mortar and concrete but would however require further experimentation.

It takes a reasonably long time for changes in $\mathrm{pH}$ levels at the concrete surface and the subsequent initiation and progress of concrete corrosion caused by sulfide induced concrete corrosion due to the SOB activity. Therefore, accelerated corrosion was used to reduce the time of testing. To simulate resistance to sulfuric acid attack, an induced accelerated corrosion technique was used by immersion of samples containing $0 \%, 5 \%$ and $10 \%$ mullite in sulfuric acid of $\mathrm{pH} 0.25$ and 1 . Previous studies have indicated that 35 days immersion of a concrete sample in an acid bath of $\mathrm{pH} 1$ gives rise to a level of corrosion equivalent to about 20 years' service in an ordinary combined sewer [55]. The SOB was not presented in this study in order to reduce the complexity of the system for evaluation of the corrosion properties of mortars and concrete samples.

Immersion in sulfuric acid of $\mathrm{pH} 0.25$ for two weeks was performed to evaluate the corrosion resistance properties of samples containing mullite. Concrete hardly ever experiences such a harsh environment in its service life. Control samples containing $0 \%$ mullite (F1 and F4) dissolved in acid media, as expected. Samples containing 5\% and 10\% mullite, in contrast, survived in such a harsh condition. The images of the survived samples are shown in the first row of Figure 2. Both mortar and concrete samples containing $10 \%$ mullite have a thinner white layer $(<2 \mathrm{~mm})$ which is attributed to a corrosion zone as compared to the $5 \%$ samples. 


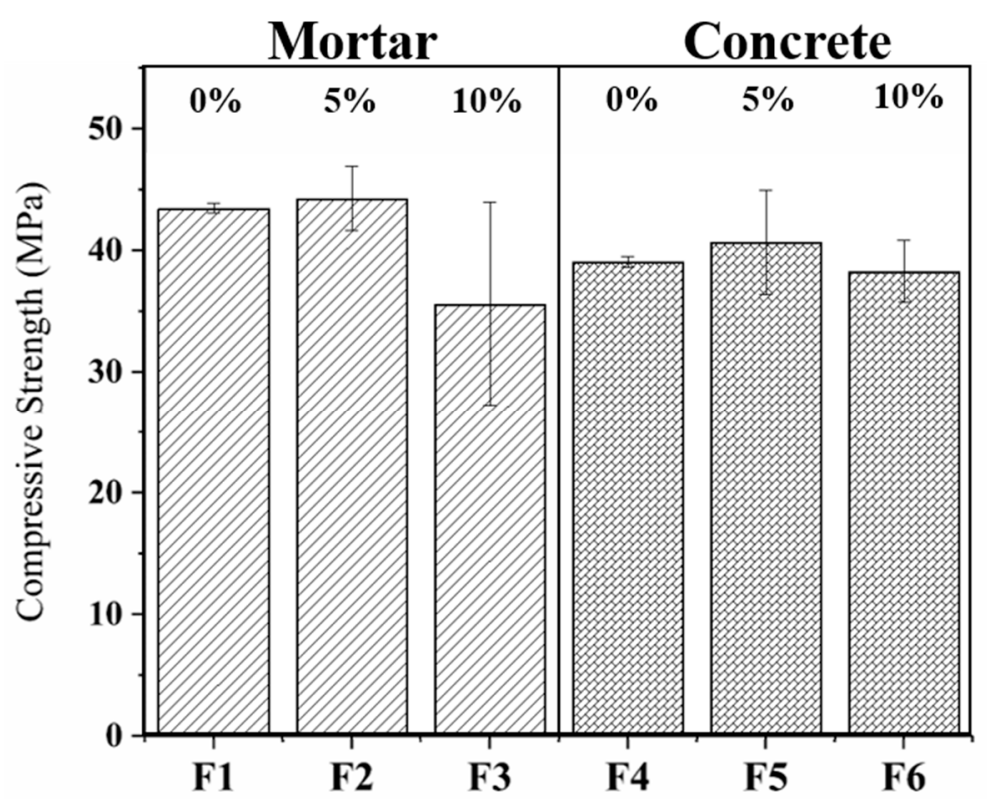

Figure 1. Compressive Strength (MPa) of mortar and concrete samples with 0,5 and 10 weight percent of mullite.

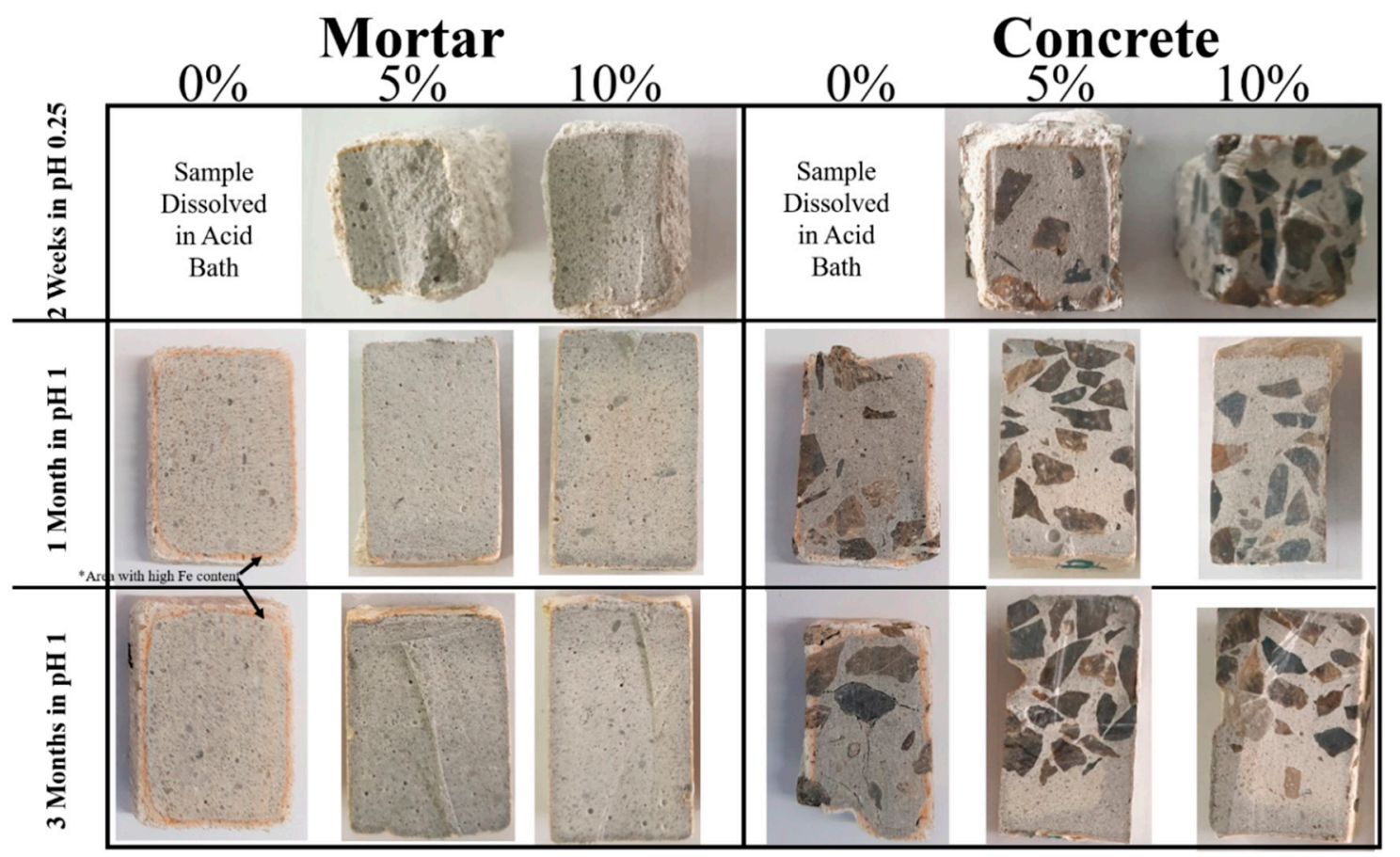

Figure 2. Images of mortar and concrete samples containing $0 \%, 5 \%$ and $10 \%$ mullite immersed in the acid bath $\mathrm{pH} 1$ for the duration of 1 and 3 months and in the $\mathrm{pH} 0.25$ for the duration of 2 weeks. Control samples containing $0 \%$ mullite were dissolved in the acid bath of $\mathrm{pH} 0.25$ in 2 weeks, therefore there are no pictures being display. * Golden brownish areas (as shown by black arrows in $1 \mathrm{M}$ and $3 \mathrm{M}$ mortar samples) are iron rich zones.

A proper experiment was designed to study the corrosion properties of samples in the acid bath by using a solution of diluted sulfuric acid of $\mathrm{pH} 1$. The $\mathrm{pH}$ was continuously and manually monitored by adding a diluted sulfuric acid solution to keep the $\mathrm{pH}$ constant for the duration of 3-month test. Samples were rotated occasionally so all surface directions were exposed to a similar acidic environment. 
The release of the entrapped air from the sample pores and the $\mathrm{CO}_{2}$ bubbles from the sample surface started almost immediately, after samples were submerged in the acid bath and lasted for a few hours. The reaction between the sulfuric acid and the calcium carbonate forms $\mathrm{CO}_{2}$ bubbles and the carbonate dissolves of in favor of the formation of sulfates. We observed precipitation of corroded byproducts on the bath floor starting from the third week. Gypsum $\left(\mathrm{CaSO}_{4} \cdot 2 \mathrm{H}_{2} \mathrm{O}\right)$ was detected in the sediments based on the absorption peaks and corresponding chemical bonds measured FTIR spectroscopy (data not provided). Discoloration and whitening of control samples (F1 and F4) were noticeable on the surface of samples inside the acid bath from the second week and other samples containing mullite from the third week. The findings from one of our previous studies showed that the discoloration and dissolution of materials in the acid bath is due to the partial loss of calcium caused by the penetration of sulfur into the sample, and formation of gypsum $\left(\mathrm{CaSO}_{4} \cdot 2 \mathrm{H}_{2} \mathrm{O}\right)$ due to the reaction of the sulfur with the remaining calcium in the cement paste. Corrosion byproducts have weak cohesive strength properties; thus, they detach easily over time. The gypsum in the bath can also form as the result of the reaction between the leached calcium and the sulfate in the bath and the presence of gypsum in the bath is connected to the level of $\mathrm{H}^{+}$.

Samples were removed from the bath after periods of 1 and 3 months, washed thoroughly with water and dried. They were then visually inspected for any change in their external appearance. These samples were then cut in half and the depth of corrosion was determined visually (Figure 2). All samples have a thin white layer, corrosion zone, surrounding the grayish area, the intact zone. The corroded layer can be clearly seen to be a much lighter color than the bulk concrete cement-paste. The corrosion zone progressed with time in control samples (F1 and F4), as measured by the thickness of the white layer, while there are no changes in the corrosion zone of $1 \mathrm{M}$ and $3 \mathrm{M}$ immersed samples (Figure 2).

False color elemental maps produced from our $\mu$-XRF data, Figure 3, show the distribution of $S$ (red), and Ca (blue) in the present work. The color and intensity of a pixel in an image is proportional to the elements present in that pixel and their concentration. The color and intensity of a pixel in an image is proportional to the elements present in that pixel and their concentration. Thus, when there is an even distribution of $\mathrm{Ca}$ and $\mathrm{S}$, the area looks purple. The presence of $\mathrm{Ca}$ in the uncorroded areas of samples is seen to be higher than the corroded areas. Sulfur can be seen to accumulate mainly in the outer corroded zone, and the thickness of the S-rich zone increases with immersion duration. The comparison of the visual color changes (Figure 2) and the elemental maps (Figure 3) reveals that the degree acid attack corresponds to the visual color changes in the specimens. Although the results of the elemental maps of $\mathrm{Fe}, \mathrm{Al}$ and $\mathrm{Mg}$ are not shown, a lower concentration of those elements was found in the corroded zone of all samples and iron is seen to exist in a zone between the sulfur and calcium (the golden brownish ring highlighted in Figure 2). We infer that the color changes in the corroded zone can also be correlated to the absence of elements such as $\mathrm{Ca}, \mathrm{Mg}$, Fe (in addition to the formation of gypsum). We considered the area with visible color changes as the "corrosion front" and then measured the progress of the depth of this area, using optical microscopy. This measurement was performed from the exposed surface of the concrete to the color changes (from light purple to intense blue) with considering the extent of the lost matter. The thickness of corroded layer in accelerated conditions is plotted in Figure 4 as a function of time. The rate of corrosion was found to be $0.060 \mathrm{~mm} /$ day in the first month and then reduced to $0.035 \mathrm{~mm}$ /day from the second month for both control mortar and concrete samples (F1 and F4). Linear fitted line obtained with R2 value shows that there is a good correlation between the immersion time and the corrosion rate $(\mathrm{R} 2>0.7)$. Mortar samples containing mullite were corroded at the rate of $0.005 \mathrm{~mm} /$ day in the first month and then $0.002 \mathrm{~mm} /$ day from the second month, and concrete samples containing mullite were corroded at the rate of $0.004 \mathrm{~mm} /$ day in the first month and then $0.002 \mathrm{~mm} /$ day from the second month. 


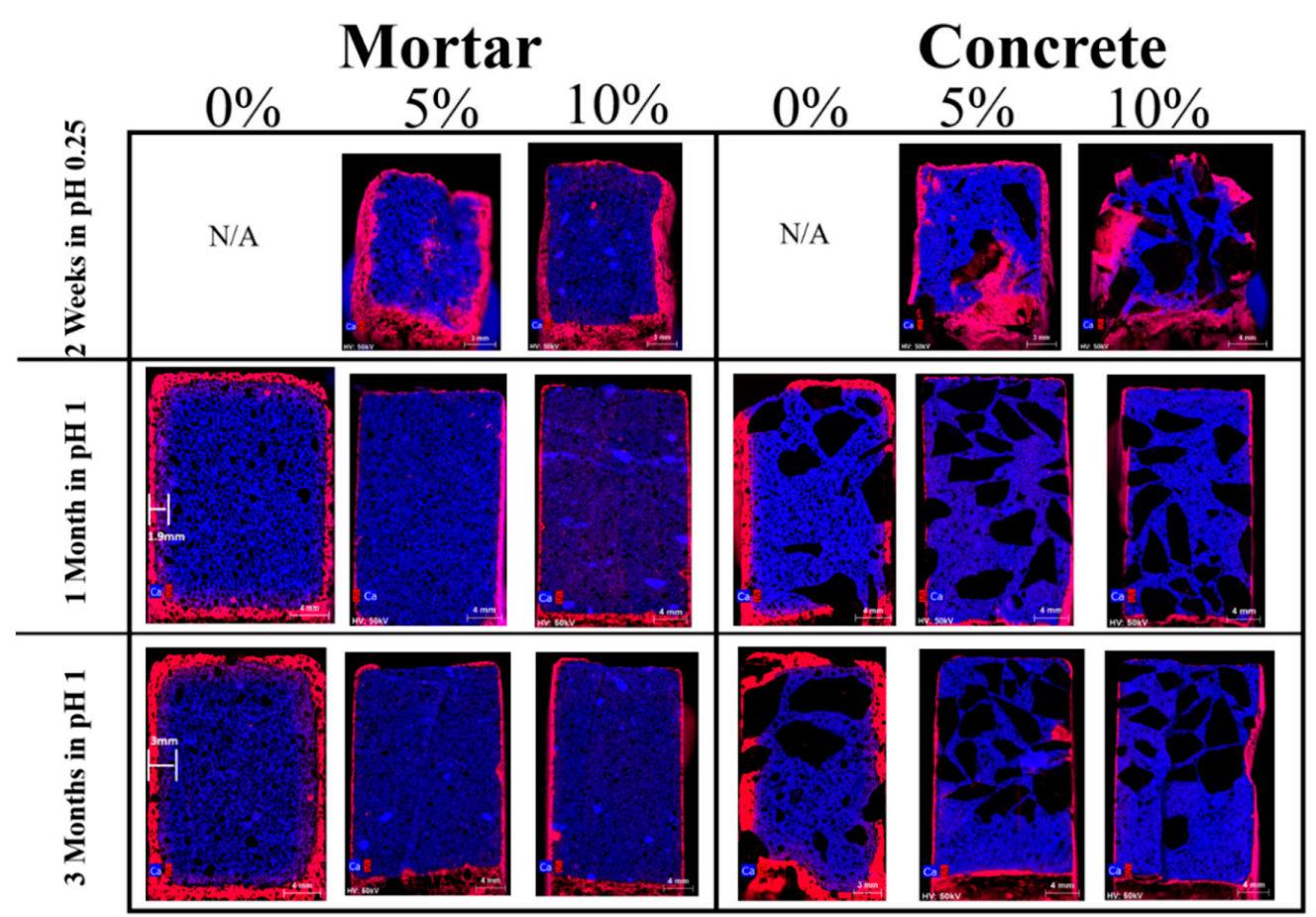

Figure 3. $\mu$-XRF (50 kV tube voltage, $35 \mu \mathrm{m}$ pixel size, $3.5 \mathrm{~mm} / \mathrm{S}$ stage speed, and pixel time of $10 \mathrm{~ms} /$ pixel) false color elemental mapping of calcium (blue) and sulfur (red) in mortar and concrete samples containing $0 \%, 5 \%$ and $10 \%$ mullite immersed in the acid bath $\mathrm{pH} 1$ for the duration of 1 and 3 months and in the $\mathrm{pH} 0.25$ for the duration of 2 weeks. Control samples containing $0 \%$ mullite were dissolved in the acid bath of $\mathrm{pH} 0.25$ in 2 weeks, therefore there are no pictures being display. Note: A sample thickness measurement of the corroded area with visible color changes (used for calculation of the rate of corrosion) is shown in $1 \mathrm{M}$ and $3 \mathrm{M}$ mortar samples.

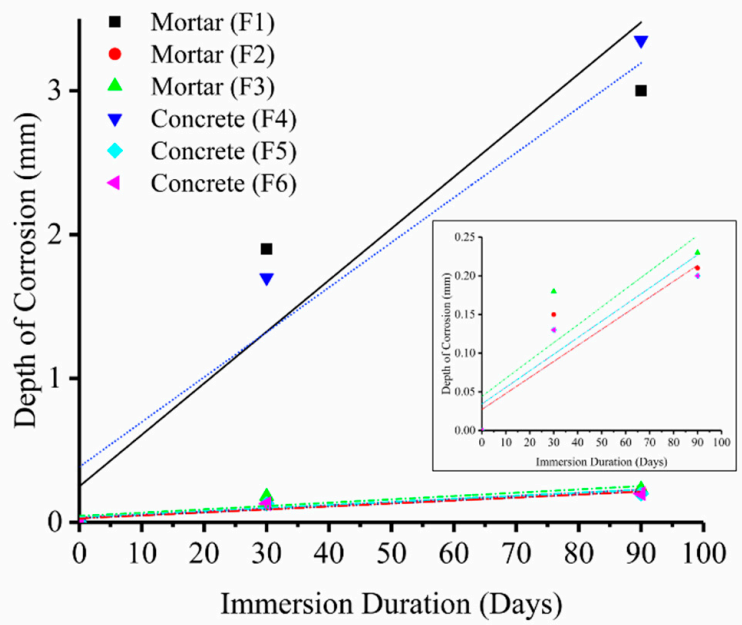

Figure 4. The thickness of the corroded layer and the depth of visible color change (corrosion) due to penetration of sulfur (red) obtained from $\mu$-XRF false color elemental mapping (Figure 3 ). The inset is the magnification of the F2, F3, F5, F6 trend. All regression lines are meant as a visual guide only.

Acid corrosion involves a series of chemical reactions that can lead to the formation of phases with characteristic morphologies. Further analysis was performed using SEM for a higher magnification examination of the morphological structure of corroded specimens, as shown in Figures 5 and 6. Morphological differences are evident between the surface and sub-surface layers compared to the bulk (intact zone). All samples were affected by the extrinsic acid attacks [56] at the surface zone $(0$ to $\sim 300 \mu \mathrm{m}$ ), while the thickness of the corroded areas (with distinct crystalline morphology) were 
dissimilar in all samples. In the formulations with $10 \%$ mullite (F3 and F6), the thickness of the corroded zone was limited to the first $100 \mu^{2}$ from the surface. The corroded area in the $5 \%$ mullite formulations (F2 and F5) was around $1000 \mu \mathrm{m}^{2}$. The depth of the corrosion in the control samples, F1 and F4 with no mullite in their formulations, were greater than $4000 \mu \mathrm{m}$ in both mortar and concrete. Based on the visual examinations and the observation of a gray cement paste from this depth onward, it was assumed that this area was uncorroded. The SEM micrograph showed that the gray color in control samples doesn't always represent the uncorroded zone. The presence of excess voids, cracks, and the detachment of sand grains/aggregates from the cement matrix were characteristics of the corroded areas.

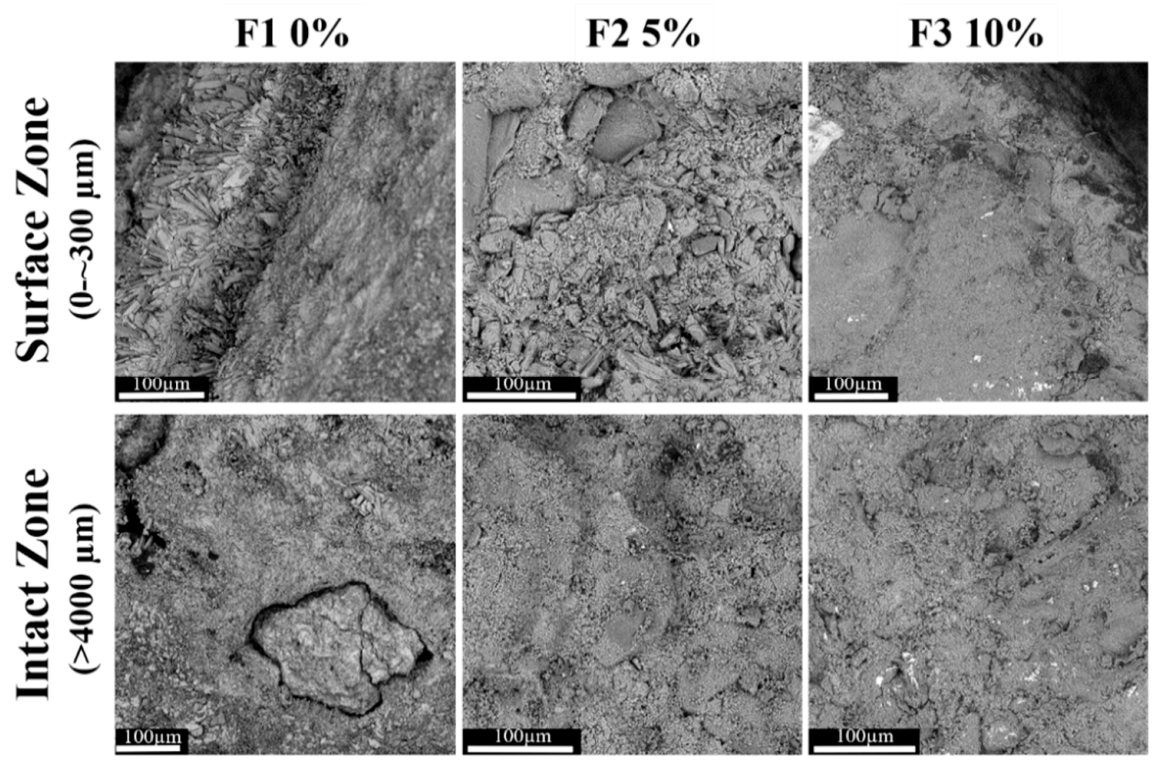

Figure 5. SEM micrograph (BSD, $10 \mathrm{kV}, 770 \times)$ of the surface zone (0 to $\sim 300 \mu \mathrm{m})$ versus the intact zone $(>5000 \mu \mathrm{m})$ of mortar samples containing $0 \%, 5 \%$ and $10 \%$ mullite and immersed in the acid bath $\mathrm{pH} 1$ for the duration of 3 months (scale bar: $100 \mu \mathrm{m}$ ).

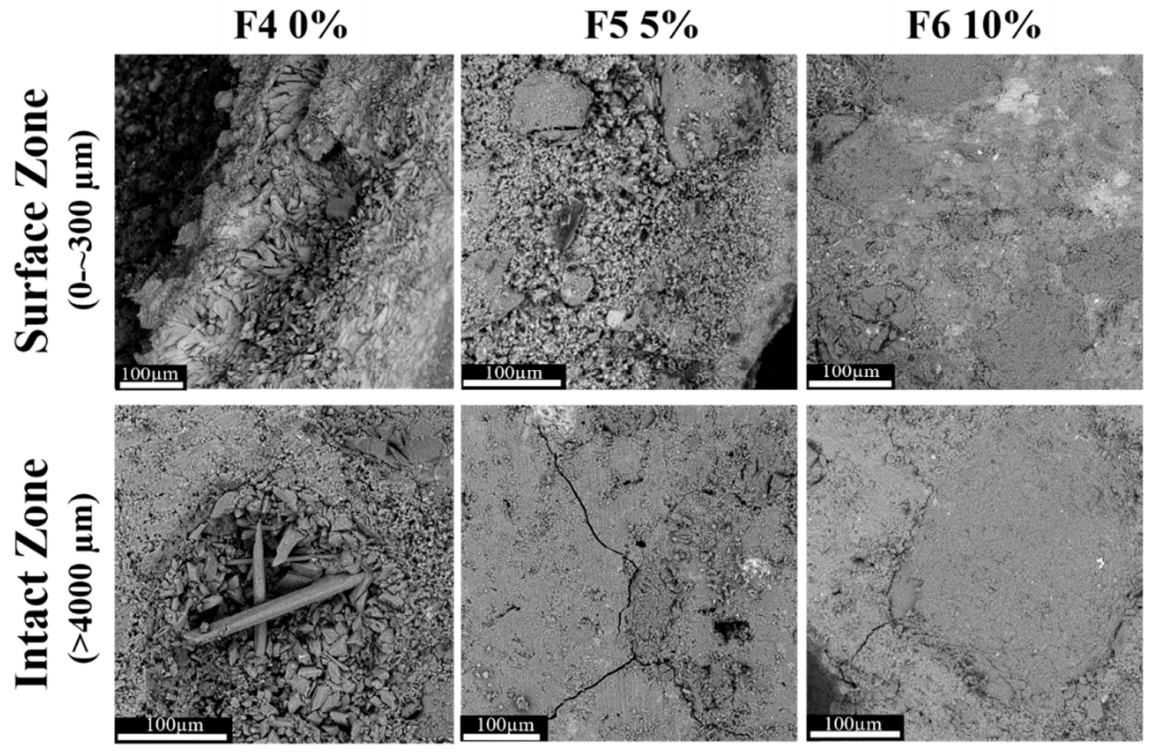

Figure 6. SEM micrograph (BSD, $10 \mathrm{kV}, 770 \times)$ of the surface zone $(0$ to $\sim 300 \mu \mathrm{m})$ versus the intact zone $(>5000 \mu \mathrm{m})$ of concrete samples containing $0 \%, 5 \%$ and $10 \%$ mullite and immersed in the acid bath $\mathrm{pH} 1$ for the duration of 3 months (scale bar: $100 \mu \mathrm{m}$ ). The observed cracks in the intact zone of samples were formed during sample cutting by diamond saw. 
Based on the SEM-EDX (data not shown) and $\mu$-XRF analysis together with visual inspection of samples, a conceptual model of acid corrosion of concrete without and with $10 \%$ mullite is developed and pictured in Figure 7. The dissolution of $\mathrm{Ca}^{2+}$ and other hydration products (from the cement-paste) and the ingress of $\mathrm{S}^{-}$(from the acid bath) resulted in the formation of rectangular gypsum $\left(\mathrm{CaSO}_{4} \cdot 2 \mathrm{H}_{2} \mathrm{O}\right)$, the secondary ettringite $\left(3 \mathrm{CaO} \cdot \mathrm{Al}_{2} \mathrm{O}_{3} \cdot 3 \mathrm{CaSO}_{4} \cdot 32 \mathrm{H}_{2} \mathrm{O}\right)$, and the calcite $\left(\mathrm{CaCO}_{3}\right)$ crystals, observed at the corroded zone [2,57-60]. In samples with high aluminum content, the corroded byproducts had shorter calcium sulfate crystals. Examination of the white spots on the SEM image by the Energy-dispersive X-ray spectroscopy (data not shown) revealed that there were areas of high aluminum content. The silica-alumina gels have much lower solubility compared to calcium salts and can act as a partial inhibitor to the overall process of corrosion by blocking tiny passage in the cement paste through which the water flows. This reduces the amount of calcium salts that enter into the solution and delays the overall process.

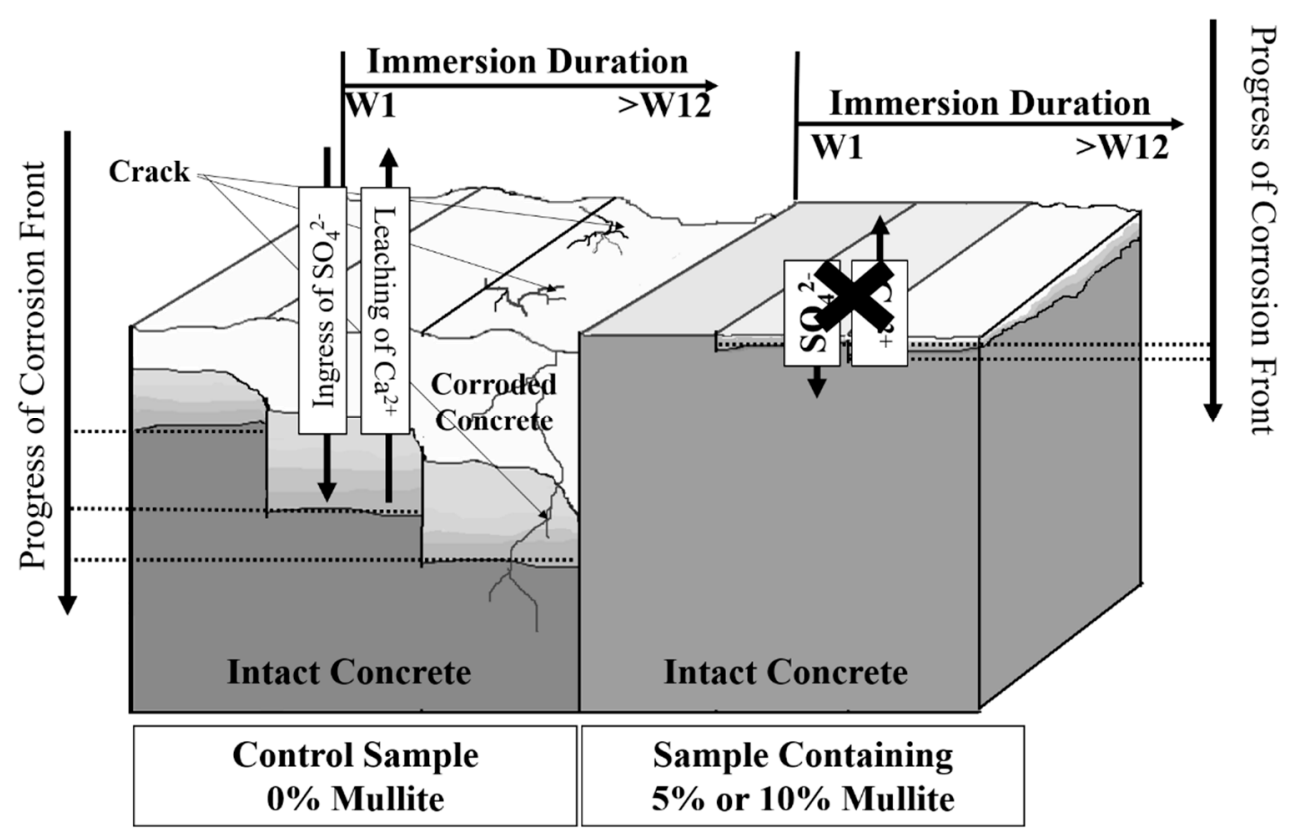

Figure 7. Schematic of progress of corrosion in concrete without and with $5 \%$ or $10 \%$ mullite immersed in the sulfuric acid bath $\mathrm{pH} 1$; white area represents the corrosion front, and light gray area is the transition zone, the intact concrete is shown with darker gray color.

Finally, apparent hardness values were measured using a microindentation Vickers hardness testing device. The measurement was performed from the surface zone (exposed to the acid solution) to a depth of $12 \mathrm{~mm}$, Figure 8. The obtained hardness values show the severity of the acid attack and the softness of the corrosion byproducts demonstrating that the mix design can play a key role in the durability of concrete exposed to a harsh environment. The depth of softness in control mortar and concrete samples (F1 and F4) with $0 \%$ mullite is up to $6 \mathrm{~mm}$. This softening can be correlated to calcium depletion (Figure 3). The surface of mortar and concrete samples with $5 \%$ and $10 \%$ mullite is slightly softer than the intact zone, however, the overall strength did not significantly alter from the surface to the bulk. This indicates that the dissolution of calcium hydroxide $(\mathrm{C}-\mathrm{H})$ from the cement-paste and the loss of calcium did not occur in samples containing a high amount of aluminum silicate in the form of mullite [61]. The intact zone (depth of 10-12 mm) of control, F1 and F4, samples have a higher strength than samples with $5 \%$ and $10 \%$ mullite.

The rate of corrosion and hardness results confirm that mullite can reduce the rate of corrosion by almost $90 \%$ (the service life of a pipe is expected to be increased by a factor of 3 ). In this study, we only focused on the sulfate attack. Given the complicated nature of concrete corrosion, we cannot simply 
calculate the service life extension using our limited data, but we can expect that the maintenance costs, due to acid corrosion, will be reduced tremendously when mullite is used in the concrete formulation.
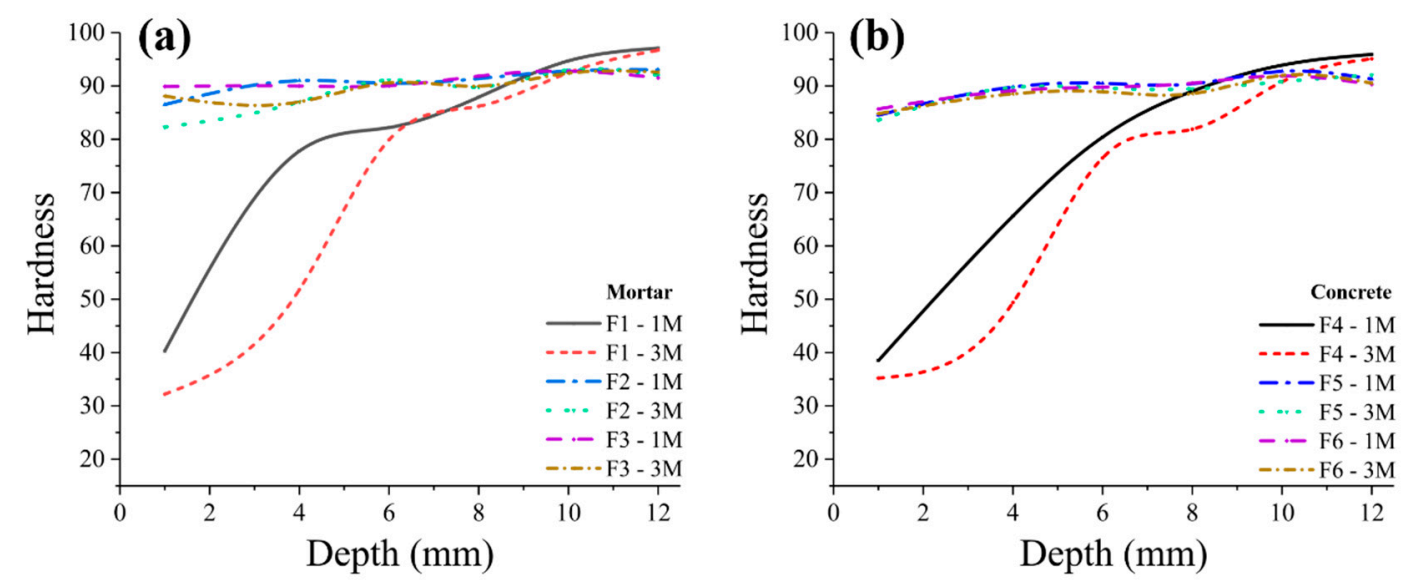

Figure 8. Hardness profile of mortar (a) and concrete (b) samples after immersion in the acid bath over a duration of 3 months.

\section{Conclusions}

This study demonstrated that the use of mullite in concrete has technical and economic benefits. It can inhibit the progress of corrosion, the penetration of sulfur and the loss of calcium, and maintain the overall hardness of mortar and concrete samples. This is due to the lower solubility of silica-alumina gels formed at the surface of samples with a high amount of aluminum silicate that prevent the leaching of calcium salts and consequently delay the overall corrosion process. From this study, it can be concluded that the concrete mix design plays a key role in the rate of corrosion over time. Both control mortar and concrete samples (F1 and F4) were corroded at the rate of $0.035 \mathrm{~mm} /$ day, while $5 \%$ and $10 \%$ concrete and mortar samples showed a corrosion rate of $0.002 \mathrm{~mm} /$ day from the second month.

- The presence of $\mathrm{Ca}$ in the surface zone of 5\% and 10\% corroded samples is seen to be higher than in the control corroded samples. The extrinsic acid attack promotes decalcification of calcium-silicate-hydrate (C-S-H) and leaching of free $\mathrm{Ca}^{2+}$, thus the corroded areas are depleted in $\mathrm{Ca}$ and appeared whiter. The formation of silica-alumina gels in 5\% and 10\% mortar and samples seems to slow than this process and protect the samples from the ingress of invasive ions and rapid break down.

- The depth of microstructural changes, due to the formation of corrosion byproducts, in the control samples (F1 and F4, 0\% mullite), was greater than $4000 \mu \mathrm{m}$, while in the $5 \%$ mullite formulations (F2 and F5) was around $1000 \mu^{2}$, and in the $10 \%$ mullite formulations (F3 and F6), the depth of microstructural changes was limited to the first $100 \mu \mathrm{m}^{2}$ from the surface.

- With the increase of immersion time, control samples became softer at surface. This can be due to the formation of corrosion byproducts (such as gypsum) as well as decalcification of cement-paste. On average we detected a significant change in hardness as a function of depth in control mortar and concrete samples ( $0 \%$ mullite) with approximately $60 \%$ decrease in the hardness at the surface exposed to acidic media, and the depth of softening in three months corroded samples was almost up to $6 \mathrm{~mm}$. Samples containing 5\% and 10\% mullite had a smaller corroded area compared to control samples, and that hardness did not really change with depth in those samples.

Results of this investigation can be used to improve the performance of concrete structures exposed to low $\mathrm{pH}$ environments. Mullite has great potential to be used as a corrosion inhibitor for cementitious products used in harsh environments such as the sewer system as by using mullite the life span of a pipe is expected to be increased and the maintenance costs are anticipated to be reduced. Further studies are required to determine the optimum amount, the alternative domestic natural 
minerals, and the most cost-effective method of fabrication of corrosion-resistant concrete. Economic concerns have been identified in using pure mullite. Thus, future studies will focus on examining the use of alternative minerals with high aluminum silicate content such as topaz and marginal bauxite deposits within Australia and the fabrication of cement-based coatings containing mullite for the lining of concrete products. However, if we consider the fact that mullite reduced the rate of corrosion by $90 \%$ in this study, the gross benefit of the addition of mullite to asset owners is reduction in asset life cycle costs.

Author Contributions: G.P.D. and S.T. conceived of the presented idea and prepared samples; S.T. planned the experiments, worked out almost all of the technical details, and wrote the paper; P.G. performed the compression strength tests; S.T. performed accelerated corrosion studies, SEM, and hardness tests; O.B.A.A. performed the $\mu$-XRF tests. S.M.C. provided the lab space and consumables. All authors provided feedback on the final version of the manuscript. All authors have read and agreed to the published version of the manuscript.

Funding: This research was funded by Macquarie University Research Fellowship 2018.

Acknowledgments: This study is derived from a 2019 Science Extension Course for year 12 students developed by NSW Education Standards Authority (NESA). GPD would like to thank Rohan Isaac and St Andrew's College Marayong from the Catholic Education Diocese of Parramatta for their help and support. ST thank Macquarie University for support through Macquarie University Research Fellowship 2018 (MQRF2018). We acknowledge the use of Structural Research and Testing laboratory facilities at the Western Sydney University, as well as facilities at GeoAnalytical laboratories at Macquarie University, and thank staff for their support. Prof. Bijan Samali and Robert Marshall from Western Sydney University, Timothy D. Murphy, Chao Shen, Vahik Avakian, and Manal Bebbington from Macquarie University are acknowledged for their technical support.

Conflicts of Interest: The authors declare no conflict of interest.

\section{References}

1. Marcos-Meson, V.; Fischer, G.; Edvardsen, C.; Skovhus, T.L.; Michel, A. Durability of Steel Fibre Reinforced Concrete (SFRC) exposed to acid attack-A literature review. Constr. Build. Mater. 2019, 200, 490-501. [CrossRef]

2. Taheri, S.; Ams, M.; Bustamante, H.; Vorreiter, L.; Bevitt, J.J.; Withford, M.; Clark, S.M. Characterizing Concrete Corrosion Below Sewer Tidal Levels at Chemically Dosed Locations. Water Res. 2020. [CrossRef] [PubMed]

3. Wiener, M.S.; Salas, B.V. Corrosion of the marine infrastructure in polluted seaports. Corros. Eng. Sci. Technol. 2005, 40, 137-142.

4. Erbektas, A.R.; Isgor, O.B.; Weiss, W.J. Comparison of Chemical and Biogenic Acid Attack on Concrete. ACI Mater. J. 2020, 117, 255-264. [CrossRef]

5. Allahverdi, A.; Škvára, F. Acidic corrosion of hydrated cement based materials. Ceram. Silik. 2000, 44, 152-160.

6. Sersale, R.; Frigione, G.; Bonavita, L. Acid depositions and concrete attack: Main influences. Cem. Concr. Res. 1998, 28, 19-24. [CrossRef]

7. Song, Y.; Wightman, E.; Kulandaivelu, J.; Bu, H.; Wang, Z.; Yuan, Z.; Jiang, G. Rebar corrosion and its interaction with concrete degradation in reinforced concrete sewers. Water Res. 2020, 182, 115961. [CrossRef]

8. Song, Y.; Wightman, E.; Tian, Y.; Jack, K.; Li, X.; Zhong, H.; Bond, P.L.; Yuan, Z.; Jiang, G. Corrosion of reinforcing steel in concrete sewers. Sci. Total Environ. 2019, 649, 739-748. [CrossRef]

9. Fattuhi, N.I.; Hughes, B.P. The performance of cement paste and concrete subjected to sulphuric acid attack. Cem. Concr. Res. 1988, 18, 545-553. [CrossRef]

10. Beddoe, R.E.; Dorner, H.W. Modelling acid attack on concrete: Part I. The essential mechanisms. Cem. Concr. Res. 2005, 35, 2333-2339. [CrossRef]

11. Romanova, A. Concrete corrosion induced by sulfuric acid. In Proceedings of the Sheffield Research Seminar, Sheffield, UK, 2 March 2016; p. 16120.

12. Irico, S.; de Meyst, L.; Qvaeschning, D.; Alonso, M.C.; Villar, K.; de Belie, N. Severe Sulfuric Acid Attack on Self-Compacting Concrete with Granulometrically Optimized Blast-Furnace Slag-Comparison of Different Test Methods. Materials 2020, 13, 1431. [CrossRef] [PubMed]

13. Revertegat, E.; Richet, C.; Gegout, P. Effect of $\mathrm{pH}$ on the durability of cement pastes. Cem. Concr. Res. 1992, 22, 259-272. [CrossRef] 
14. Cao, H.T.; Bucea, L.; Ray, A.; Yozghatlian, S. The effect of cement composition and pH of environment on sulfate resistance of Portland cements and blended cements. Cem. Concr. Compos. 1997, 19, 161-171. [CrossRef]

15. Panarese, W.C. Environmental Performance of Concrete. In ASM Handbook Volume 13B: Corrosion: Materials; ASM International: Cleveland, OH, USA, 2005; pp. 579-588. [CrossRef]

16. Ulm, F.J.; Heukamp, F.H.; Germaine, J.T. Durability mechanics of calcium leaching of concrete and beyond. Fract. Mech. Concr. Struct. 2001, 1, 133-143.

17. Hewayde, E.; Nehdi, M.; Allouche, E.; Nakhla, G. Effect of mixture design parameters and wetting-drying cycles on resistance of concrete to sulfuric acid attack. J. Mater. Civ. Eng. 2007, 19, 155-163. [CrossRef]

18. Zhou, Y.; Tian, H.; Sui, L.; Xing, F.; Han, N. Strength deterioration of concrete in sulfate environment: An experimental study and theoretical modeling. Adv. Mater. Sci. Eng. 2015, 951209. [CrossRef]

19. Islander, R.L.; Devinny, J.S.; Mansfeld, F.; Postyn, A.; Shih, H. Microbial ecology of crown corrosion in sewers. J. Environ. Eng. 1991, 117, 751-770. [CrossRef]

20. Barton, L.L.; Tomei, F.A. Characteristics and activities of sulfate-reducing bacteria. In Sulfate-Reducing Bacteria; Springer: Boston, MA, USA, 1995; pp. 1-32.

21. Huber, B.; Herzog, B.; Drewes, J.E.; Koch, K.; Müller, E. Characterization of sulfur oxidizing bacteria related to biogenic sulfuric acid corrosion in sludge digesters. BMC Microbiol. 2016, 16, 153. [CrossRef]

22. Yuan, H.; Dangla, P.; Chatellier, P.; Chaussadent, T. Degradation modeling of concrete submitted to biogenic acid attack. Cem. Concr. Res. 2015, 70, 29-38. [CrossRef]

23. Li, X.; O’Moore, L.; Song, Y.; Bond, P.L.; Yuan, Z.; Wilkie, S.; Hanzic, L.; Jiang, G. The rapid chemically induced corrosion of concrete sewers at high $\mathrm{H}_{2} \mathrm{~S}$ concentration. Water Res. 2019, 162, 95-104. [CrossRef]

24. Fattuhi, N.I.; Hughes, B.P. Ordinary Portland cement mixes with selected admixtures subjected to sulfuric acid attack. Mater. J. 1988, 85, 512-518.

25. Apté, N. Know your sewer-corrosion protection of sewer assets. In Proceedings of the 78th WIOA Victorian Water Industry Operations Conference \& Exhibition Bendigo Exhibition Centre, Bendigo, Australia, 2-3 September 2015.

26. Ganigue, R.; Gutierrez, O.; Rootsey, R.; Yuan, Z. Chemical dosing for sulfide control in Australia: An industry survey. Water Res. 2011, 45, 6564-6574. [CrossRef] [PubMed]

27. Hewlett, P.; Liska, M. Lea's Chemistry of Cement and Concrete; Butterworth-Heinemann: Oxford, UK, 2019.

28. Mehta, P.K. Durability of concrete in marine environment-A review. Spec. Publ. 1980, 65, 1-20.

29. Dahhou, M.; Arshad, M.A.; el Moussaouiti, M. Synthesis and characterisation of Portland cement clinker by exploiting waste oyster shells and alumina sludge. Eur. J. Environ. Civ. Eng. 2019, 1-17. [CrossRef]

30. Chesley, J.; Burnet, G. A two-stage reaction sequence for C3S formation. Cem. Concr. Res. 1989, 19, 837-847. [CrossRef]

31. Tan, B.; Okoronkwo, M.U.; Kumar, A.; Ma, H. Durability of calcium sulfoaluminate cement concrete. J. Zhejiang Univ. Sci. A 2020, 21, 118-128. [CrossRef]

32. Wang, Y.; Cui, S.; Lan, M.; Tian, G.; Liu, L. Influence of characteristics of alumina-silicate raw materials on the formation process of clinker. J. Wuhan Univ. Technol. Mater. Sci. Ed. 2014, 29, 966-971. [CrossRef]

33. Gartner, E.; Sui, T. Alternative cement clinkers. Cem. Concr. Res. 2018, 114, 27-39. [CrossRef]

34. Liu, K.W.; Deng, M.; Mo, L.W. Effect of Fly Ash on Resistance to Sulfate Attack of Cement-based Materials. In Key Engineering Materials; Trans Tech Publications Ltd.: Bäch SZ, Switzerland, 2013; pp. 124-129.

35. Goyal, S.; Kumar, M.; Sidhu, D.S.; Bhattacharjee, B. Resistance of mineral admixture concrete to acid attack. J. Adv. Concr. Technol. 2009, 7, 273-283. [CrossRef]

36. Kiliswa, M.W.; Scrivener, K.L.; Alexander, M.G. The corrosion rate and microstructure of Portland cement and calcium aluminate cement-based concrete mixtures in outfall sewers: A comparative study. Cem. Concr. Res. 2019, 124, 105818. [CrossRef]

37. Li, G.; Zhang, A.; Song, Z.; Shi, C.; Wang, Y.; Zhang, J. Study on the resistance to seawater corrosion of the cementitious systems containing ordinary Portland cement or/and calcium aluminate cement. Construct. Build. Mater. 2017, 157, 852-859. [CrossRef]

38. Binici, H.; Aksoğan, O. Sulfate resistance of plain and blended cement. Cem. Concr. Compos. 2006, 28, 39-46. [CrossRef]

39. Vuk, T.; Gabrovšek, R.; Kaučič, V. The influence of mineral admixtures on sulfate resistance of limestone cement pastes aged in cold $\mathrm{MgSO}_{4}$ solution. Cem. Concr. Res. 2002, 32, 943-948. [CrossRef] 
40. Harilal, M.; Uthaman, S.; Anandkumar, B.; Lahiri, B.B.; George, R.P.; Philip, J.; Amarendra, G. Fungal resistance of nanomodifiers and corrosion inhibitor amended fly ash concrete. Int. Biodeterior. Biodegrad. 2019, 143, 104725. [CrossRef]

41. Rashad, A.M.; Seleem, H.E.-D.H.; Shaheen, A.F. Effect of Silica Fume and Slag on Compressive Strength and Abrasion Resistance of HVFA Concrete. Int. J. Concr. Struct. Mater. 2014, 8, 69-81. [CrossRef]

42. Siddique, R. Utilization of silica fume in concrete: Review of hardened properties. Resour. Conserv. Recycl. 2011, 55, 923-932. [CrossRef]

43. Jackson, M.D.; Chae, S.R.; Mulcahy, S.R.; Meral, C.; Taylor, R.; Li, P.; Emwas, A.-H.; Moon, J.; Yoon, S.; Vola, G. Unlocking the secrets of Al-tobermorite in Roman seawater concrete. Am. Mineral. 2013, 98, 1669-1687. [CrossRef]

44. Jackson, M.D.; Mulcahy, S.R.; Chen, H.; Li, Y.; Li, Q.; Cappelletti, P.; Wenk, H.-R. Phillipsite and Al-tobermorite mineral cements produced through low-temperature water-rock reactions in Roman marine concrete. Am. Mineral. 2017, 102, 1435-1450. [CrossRef]

45. Nagrockienè, D.; Girskas, G.; Skripkiūnas, G.; Daugèla, A. Properties of concrete modified by amorphous alumina silicate. Eng. Struct. Technol. 2014, 6, 178-183. [CrossRef]

46. Ma, B.; Lothenbach, B. Synthesis, characterization, and thermodynamic study of selected Na-based zeolites. Cem. Concr. Res. 2020, 135, 106111. [CrossRef]

47. Tran, Y.T.; Lee, J.; Kumar, P.; Kim, K.-H.; Lee, S.S. Natural zeolite and its application in concrete composite production. Compos. Part B Eng. 2019, 165, 354-364. [CrossRef]

48. Ranjbar, N.; Kuenzel, C. Cenospheres: A review. Fuel 2017, 207, 1-12. [CrossRef]

49. Schneider, H.; Schreuer, J.; Hildmann, B. Structure and properties of mullite-A review. J. Eur. Ceram. Soc. 2008, 28, 329-344. [CrossRef]

50. ASTM. C39/C39M-18. Standard Test Method for Compressive Strength of Cylindrical Concrete Specimens; ASTM International: West Conshohocken, PA, USA, 2018.

51. ASTM. C187-16. Standard Test Method for Amount of Water Required for Normal Consistency of Hydraulic Cement Paste; ASTM International: West Conshohocken, PA, USA, 2016.

52. Reddy, M.S.; Neeraja, D. Mechanical and durability aspects of concrete incorporating secondary aluminium slag. Resour. Eff. Technol. 2016, 2, 225-232. [CrossRef]

53. Isfahani, F.T.; Redaelli, E.; Lollini, F.; Li, W.; Bertolini, L. Effects of nanosilica on compressive strength and durability properties of concrete with different water to binder ratios. Adv. Mater. Sci. Eng. 2016, 8453567. [CrossRef]

54. Gorse, C.; Johnston, D.; Pritchard, M. A Dictionary of Construction, Surveying, and Civil Engineering; Oxford University Press: Oxford, UK, 2012.

55. Kaempfer, W.; Berndt, M. Estimation of Service Life of Concrete Pipes in Sewer Networks. Concrete Pipes in Sewer Networks. Available online: https://www.irbnet.de/daten/iconda/CIB2045.pdf (accessed on 30 July 2020).

56. Poole, A.B.; Sims, I. Concrete Petrography: A Handbook of Investigative Techniques; CRC Press: Boca Raton, FL, USA, 2016.

57. Mori, T.; Nonaka, T.; Tazaki, K.; Koga, M.; Hikosaka, Y.; Noda, S. Interactions of nutrients, moisture and pH on microbial corrosion of concrete sewer pipes. Water Res. 1992, 26, 29-37. [CrossRef]

58. Santhanam, M.; Cohen, M.D.; Olek, J. Mechanism of sulfate attack: A fresh look. Cem. Concr. Res. 2003, 33, 341-346. [CrossRef]

59. Santhanam, M.; Cohen, M.D.; Olek, J. Effects of gypsum formation on the performance of cement mortars during external sulfate attack. Cem. Concr. Res. 2003, 33, 325-332. [CrossRef]

60. Wang, Y.; Yu, J.; Wang, J.; Guan, X. Effects of Aluminum Sulfate and Quicklime/Fluorgypsum Ratio on the Properties of Calcium Sulfoaluminate (CSA) Cement-Based Double Liquid Grouting Materials. Materials 2019, 12, 1222. [CrossRef]

61. Chen, J.J.; Thomas, J.J.; Jennings, H.M. Decalcification shrinkage of cement paste. Cem. Concr. Res. 2006, 36, 801-809. [CrossRef]

(C) 2020 by the authors. Licensee MDPI, Basel, Switzerland. This article is an open access article distributed under the terms and conditions of the Creative Commons Attribution (CC BY) license (http://creativecommons.org/licenses/by/4.0/). 